\title{
Profil Tingkat Kesegaran Jasmani Siswa Kelas IV dan V Sekolah Dasar Indonesia Kota Kinabalu Tahun Ajaran 2018/2019
}

\author{
Maulana Ischaq ${ }^{1,2}$, Endang Sri Hanani ${ }^{1,2}$, Anugrah Agus $^{2}$, Nur Nadzirah Binti Abdul Latip ${ }^{3}$ \\ ${ }^{1}$ Universitas Negeri Semarang, ,Indonesia \\ ${ }^{2}$ Universiti Malaysia Sabah, Kinabalu Malaysia \\ ${ }^{3}$ Universiti Kolej Malaysian Academic Sosial and Advertisement, Malaysia
}

\section{Info Artikel}

SejarahArtikel:

Diterima Desember 2018

Disetujui Maret 2019

Dipublikasikan Mei 2019

Keywords:

Elementary School Students, Physical Fitness

\begin{abstract}
Abstrak
Tujuan dalam penelitian ini adalah untuk mengetahui untuk profil tingkat kesegaran jasmani siswa kelas IV dan V SD SIKK (Sekolah Indonesia Kota Kinablu) Sabah Malaysia tahun ajaran 2018/2019. Metode penelitian ini adalah jenis Kuantitatif. Pengumpulan data menggunakan teknik survei tes Asia Commite on the Standardization of Physical Test (ACSPFT) untuk usia kurang dari 12 Tahun. Analisis data yang digunakan menggunakan deskriptif presentase. Hasil penelitian menunjukkan bahwa Profil Kesegaran Jasmani siswa kelas IV sebagai berikut, baik sekali $0 \%$, kategori baik 7\%, kategori cukup 46\%, kategori kurang 36\%, kategori kurang sekali $11 \%$. Profil Kesegaran Jasmani siswa kelas V baik sekali 4\%, kategori baik 20\%, kategori cukup 47\%, kategori kurang 22\%, kategori kurang sekali 7\%. Dari hasil penelitian menunjukan profil kesegaran jasmani siswa Kelas IV dan V SD SIKK Sabah Malaysia rata-rata dalam kategori cukup.
\end{abstract}

\begin{abstract}
The purpose of this study was to investigate the physical fitness level profile of fourth grade and fifth elementary school students of SD SIKK (Kinablu City School Indonesia Sabah Malaysia) in the academic year 2018/2019. It's used quantitative method. Data collection used the Asian Committee on the Standardization of Physical Test (ACSPFT) technique for under 12 years old. Data analysis used using descriptive percentages. The results showed that physical fitness profile of fourth grade elementary school students were excellent $0 \%$, good $7 \%$, fair $46 \%$, poor $2036 \%$, very poor $11 \%$. The physical fitness profile of fifth grade elementary school students were very good 4\%, good category $20 \%$, fair $47 \%$, poor $22 \%$, very poor category $7 \%$. This reseach conclude that physical fitness condition of fourth grade and fifth elementary school students of SD SIKK was in fair category.
\end{abstract}




\section{PENDAHULUAN}

Pendidikan adalah usaha yang terencana untuk mewujudkan suasana dan proses pembelajaran yang melibatkan siswa berperan aktif untuk mengembangkan potensi yang terdapat didalam dirinya seperti: kecerdasan, keterampilan, spiritual (keagamaan), akhlak mulia dan sosial. Pendidikan jasmani termasuk secara integral merupakan bagian dari pendidikan secara keseluruhan. Pendidikan jasmani merupakan proses interaksi antara peserta didik dengan lingkungan, melalui aktivitas jasmani yang dikelola secara sistematik untuk menuju manusia indonesia seutuhnya (Harsuki, 2003). Pendidikan jasmani adalah suatu proses pembelajaran melalui aktivitas jasmani yang didesain untuk meningkatkan kesegaran jasmani, mengembangkan keterampilan motorik, pengetahuan dan prilaku hidup sehat dan aktif, sikap sportif serta kecerdasan emosi (Samsudin, 2008).

Pendidikan jasmani merupakan bagian terpenting untuk seorang peserta didik guna memiliki tingkat kesegaran jasmani yang baik yang bertujuan untuk menunjang prestasi dan proses pelaksanaan pembelajaran. Karena didalam jiwa yang sehat terdapat tubuh yang kuat. Kesehatan adalah merupakan hal yang terpenting karena dengan sehat. Sehat adalah sejahtera jasmani, rohani dan sosial, bukan hanya bebas dari penyakit, cacat ataupun kelemahan manusia dapat melakukan kegiatan sehari-hari (Giriwijiyo \& Sidik2013).

Kesegaran jasmani merupakan prinsip utama dalam pendidikan jasmani, dengan mengajak siswa untuk berpartisipasi dan berperan aktif dalam proses pembelajaran guna terciptanya derajat kesegaran jasmani yang baik, dalam upaya ini diharapkan dapat mem bentuk karakter siswa menjadi lebih aktif dalam melakukan gerak dan olahraga, untuk mencapai semua tujuan itu maka seorang guru penjas harus berperan dalam menciptakan suatu tujuan yaitu tercapainya derajat kesegaran jasmani siswa. Oleh karena itu, dalam pendidikan jasmani seorang peserta didik memerlukan kesegaran jasmani yang dapat menunjang pelaksanaan pembelajaran dan membantu aktivitas fisik dalam kehidupan sehari-hari (Gilar, 2017). Kesegaran jasmani akan mengantarkan anak didik menuju kesiapan jasmani, mental dan emosional, kematangan psikologis dan fisik, serta mengantarkan anak untuk semangat belajar dan berlatih sehingga akan tercapai belajar yang diharapkan (Wirnantika, dkk. 2017).

Kesegaran jasmani merupakan bagian dari keadaan fisik seseorang untuk menunjang kegiatan dan aktivitas sehari-hari. Kesegaran jasmani juga merupakan kemampuan untuk dapat melaksanakan tugas sehari-hari dengan semangat tanpa rasa lelah yang berlebihan, dan dengan penuh energi melakukan untuk menikmati kegiatan pada waktu luang sehingga dapat menghadapi keadaan darurat bila datang (Abdullah \& Manaaji, 1994). Kesegaran jasmani tergantung pada dua komponen dasar, yaitu kesegaran organik dan kesegaran dinamik (Hairy, 1989). Kesegaran organik adalah sifatsifat khusus yang bersifat keturunan yang diwarisi kedua orangtua serta dipengaruhi oleh umur, dan mungkin oleh keadaan sakit atau kecelakaan. Sedangkan kesegaran dinamik mengarah kepada kesiapan kapasitas tubuh untuk bergerak dan bertindak dalam tingkatan tertentu sesuai dengan situasi yang dihadapi. Kesegaran jasmani di pengaruhi oleh beberapa 
faktor diantaranya faktor makanan dan gizi, faktor tidur dan faktor istirahat, faktor kebiasaan hidup sehat, dan faktor latihan olahraga atau latihan jasmani (Mukholid, 2004).

Penelitian ini dilaksankan di SD SIKK (Sekolah Indonesia Kota Kinabalu) Sabah Malaysia. Berdasarkan observasi awal diperoleh hasil sebagai berikut; . 1) Belum pernah dilakukan tes kesegaran jasmani terutama kelas IV dan V sehingga guru penjasorkes tidak mempunyai data/rekam jejak yang pasti. 2) Belum adanya program pembinaan aktivitas jasmani diluar jam pembelajaran sekolah karena hanya ada tambahan ekstrakulikuler yang di adakan 1 kali dalam seminggu, kemudian terlihat pada saat pembelajaran penjasorkes sebagian besar siswa mengeluh capek, dan mudah lesu sehingga meminta istrirahat lebih awal. 3) Siswa kekurangan waktu istirahat karena untuk kesekolah mereka berangkat jam 4-5 pagi, sehingga waktu istirahat mereka tidak maksimal. 4) Untuk pembelajaran penjasorkes di SD SIKK (Sekolah Indonesia Kota Kinabalu) sudah baik dan sudah menggunakan K13 (Kurikulum 2013) dengan durasi waktu $4 \times 35$ menit hanya dilakukan 1 kali dalam seminggu, jika dikaitkan untuk tuntutan siswa memiliki kesegaran jasmani yang baik dirasa kurang, mengingat minimal untuk memiliki tingkat kesegaran jasmani yang baik seseorang tersebut harus melakukan olahraga 3 kali dlam seminggu. Untuk media pembelajaran masih kekurangan seperti: bola, kit atletik, dan lain-lain. Sehingga media-media pembelajaran menggunakan media yang digunakan untuk anak

SMP dan SMA. Kemudian ketika jam pembelajaran penjasorkes dilakukan secara bersamaan akan mengalami kekurangan media pembelajaran ketika harus menggunakan alat karena harus berbagi baik SD, SMP maupun SMA.

Adapun permasalahan dalam penelitian ini adalah (1) Jam pembelajaran penjasorkes di sekolah SD SIKK (Sekolah Indonesia Kota Kinbalu) belum memadai jika dikaitkan dengan tuntutan dalam meningkatkan profil tingkat kesegaran jasmani siswa. (2) Belum adanya program pembinaan dalam pemeliharaan tentang profil tingkat kesegaran jasmani siswa kelas IV dan V di SD SIKK (Sekolah Indonesia Kota Kinbalu) di luar jam pembelajaran.

Tujuan dalam penelitian ini adalah untuk mengetahui tingkat kesegaran jasmani siswa kelas IV dan V SD SIKK (Sekolah Indonesia Kota Kinabalu)

\section{METODE PENELITIAN}

Metode Jenis dalam penelitian ini adalah survei tes (Arikunto, 2010). Variabel dalam penelitian ini adalah proses pembelajaran penjasorkes di SD SIKK (Sekolah Indonesia Kota Kinabalu), dan profil tingkat kesegaran jasmani siswa SD SIKK (Sekolah Indonesia Kota Kinabalu).

\section{Populasi}

Populasi dalam penelitian ini adalah seluruh siswa kelas IV dan V SD SIKK (Sekolah Indonesia Kota Kinabalu) dengan jumlah sebagai berikut:

Tabel 1. Jumlah Populasi

\begin{tabular}{llll}
\hline Kelas & Putra & Putri & Jumlah \\
\hline IV & 29 & 30 & 59 \\
V & 29 & 31 & 60 \\
Jumlah & 58 & 61 & 119 \\
\hline
\end{tabular}




\section{Instrumen Penelitian}

Instrumen dalam penelitian ini adalah ACSPFT (Asia Commite on the Standardization of Physical Test) untuk siswa SD yang berusia kurang dari 12 tahun. ACSPFT merupakan cabang dari badan organisasi internasional yang sasaran kegiatannya menyusun dan membakukan berbagai bentuk tes kesegaran jasmani yang bernama ICSPFT (international Committe on the Standardization of Physical Test). Di Asia, atas prakarsa dari negara-negara Asia Telah dibentuk satu organisasi yang sama dan merupakan anak dari I.C.S.P.F.T, yang sasaran kegiatannya ditujukan untuk negara dan bangsa Asia. Organisasi tersebut bernama: ACSPFT (Asia Commite on the Standardization of Physical Test)

Tes ACSPFT (Asia Commite on the Standardization of Physical Test) adalah salah satu alat ukur internasional yang ditujukan untuk bangsa Asia yang terdiri dari 7 (tujuh) butir tes antara lain: lari sprint 50 meter, lompat jauh tanpa awalan, bergantung siku tekuk, lari hilir mudik 4x10 meter, baring duduk 30 detik, kelentukan togok kedepan dan lari 600 meter. Ketujuh butir tes tersebut harus dilaksanakan untuk megukur tingkat kesegaran jasmani seseorang (Depdikbud:1977)

Tabel 2. Norma Tes Penilaian Kesegaran Jasmani

\begin{tabular}{ll}
\hline Jumlah Nilai T & Klasifikasi \\
\hline $434-$ ke atas & Baik Sekali (BS) \\
$387-433$ & Baik (B) \\
$335-386$ & Cukup (C) \\
$284-334$ & Kuran (K) \\
Ke bawah -283 & Kurang Sekali (KS) \\
\hline
\end{tabular}

Tabel 3. Norma Tes Penilaian Kesegaran Jasmani ACSPFT Putri Kurang dari 12 Tahun

\begin{tabular}{ll}
\hline Jumlah Nilai T & Klasifikasi \\
\hline $406-$ ke atas & Baik Sekali (BS) \\
$359-433$ & Baik (B) \\
$310-358$ & Cukup (C) \\
$265-309$ & Kuran (K) \\
Ke bawah -264 & Kurang Sekali (KS) \\
\hline
\end{tabular}

\section{Teknik Analisis Data}

Teknik analisi dalam penelitian ini menggunakan statistik deskriptif presentase (Sugiyono, 2012).

\section{HASIL PENELITIAN}

Tabel 4. Presentase hasil tes kesegaran jasmani menggunakan ACSPFT siswa kelas IV

\begin{tabular}{lcc}
\hline Kategori & N & \% \\
\hline Baik Sekali & 0 & $0 \%$ \\
Baik & 4 & $7 \%$ \\
Cukup & 25 & $46 \%$ \\
Kurang & 20 & $36 \%$ \\
Kurang Sekali & 6 & $11 \%$ \\
\hline Jumlah & 55 & $100 \%$ \\
\hline
\end{tabular}

Berdasarkan tabel 4 diperoleh hasil profil kesegaran jasmani siswa kelas IV SD SIKK (Sekolah Indonesia Kota Kinabalu) Sabah Malaysia, diperoleh hasil sebagai berikut, dari seluruh jumlah siswa kelas IV yaitu 55 orang didapat hasil berbagai kategori diantaranya kategori baik sekali 0 (0\%), kategori baik 4 (7\%), kategori cukup 25 (46\%), kategori kurang 20 (36\%), kategori kurang sekali 6 (11\%). 
Tabel 5. Presentase hasil tes kesegaran jasmani menggunakan ACSPFT siswa kelas V

\begin{tabular}{lcc}
\hline Kategori & $\mathbf{N}$ & $\mathbf{\%}$ \\
\hline Baik Sekali & 2 & $4 \%$ \\
Baik & 11 & $20 \%$ \\
Cukup & 26 & $47 \%$ \\
Kurang & 12 & $22 \%$ \\
Kurang Sekali & 4 & $7 \%$ \\
\hline Jumlah & 55 & $100 \%$ \\
\hline
\end{tabular}

Berdasarkan tabel 5 Dari seluruh jumlah siswa kelas $\mathrm{V}$ yaitu 55 orang didapat hasil berbagai kategori diantaranya baik sekali 2 (4 $\%$ ), kategori baik 11 (20\%), kategori cukup 26 (47\%), kategori kurang 12 (22\%), kategori kurang sekali 4 (7 \%).

Tabel 6. Presentase hasil tes kesegaran jasmani menggunakan ACSPFT siswa kelas IV dan V

\begin{tabular}{|c|c|c|}
\hline Kategori & $\overline{\mathbf{N}}$ & $\%$ \\
\hline Baik Sekali & 2 & $2 \%$ \\
\hline Baik & 15 & $13 \%$ \\
\hline Cukup & 51 & $46 \%$ \\
\hline Kurang & 32 & $30 \%$ \\
\hline Kurang Sekali & 10 & $9 \%$ \\
\hline Jumlah & 110 & $100 \%$ \\
\hline
\end{tabular}

Berdasarkan tabel 6 Dari seluruh jumlah siswa kelas IV dan V yaitu orang didapat hasil berbagai kategori diantaranya baik sekali 2 (2 \%), kategori baik 15 (13\%), kategori cukup 51 (46\%), kategori kurang 32 (30\%), kategori kurang sekali 10 (9 \%). Dengan demikian kesegaran jasmani siswa kelas IV dan V dilihat dari ketujuh macam item tes kesegaran jasmani termasuk dalam katagori cukup.

\section{PEMBAHASAN}

SIKK (Sekolah Indonesia Kota Kinabalu) merupakan salah satu sekolah milik Pemerintah Indonesia yang berada di luar negeri, sekolah tersebut merupakan sekolah induk yang menaungi kurang lebih 200 CLC (Communty Learning Center) yang tersebar di seluruh plosok Sabah. SIKK (Sekolah Indonesia Kota Kinabalu) terdapat berbagai jenjang antara lain PAUD, TK, SD, SMP, SMA dan SMK. SD SIKK merupakan salah satu SD dimana dalam proses pembelajarannya menggunakan K13 (Kurikulum 20013). Untuk durasi waktu proses pembelajaran terutama penjasorkes adalah $4 \times 35$ menit

Berdasarkan hasil penelitian profil tingkat kesegaran jasmani siswa kelas IV dan V di SD SIKK (Sekolah Indonesia Kota Kinabalu) Sabah Malaysia Tahun Ajaran 2018/2019 menggunakan tes kesegaran jasmani ACSPFT (Asia Committee on the Standardization of Physical Fitnes Test) diperoleh hasil kelas IV dan $\mathrm{V}$ masuk dalam kategori cukup dengan presentase $46 \%$ sebanyak 51 siswa. baik sekali 2\% sebanyak 2 siswa, baik $13 \%$ sebanyak 15 siswa, kurang 30\% sebanyak 32 siswa, dan kurang sekali $9 \%$ sebanyak 10 siswa. Hal ini di pengaruhi oleh beberapa faktor diantaranya:

\section{Kesegaran Jasmani Kategori Cukup.}

Karena jam pembelajaran penjasorkes di SD SIKK (Sekolah Indonesia Kota Kinabalu) hanya dilakukan 1 kali dalam seminggu dengan durasi 4 jam (4x45 menit) itupun tidak seutuhnya praktik melainkan kepotong untuk pembukaan, penyampaian materi dan evaluasi. Dengan demikian jam pembelajaran penjasorkes di SD SIKK (Sekolah Indonesia Kota Kinabalu) belum memadai jika dikaitkan dengan tuntutan siswa untuk memiliki tingkat kesegaran jasmani yang baik. Kemudian sebagian besar tempat tinggal siswa dengan sekolah cukup jauh memakan waktu 2-3 jam perjalanan 
sehingga mempengaruhi waktu istirahat dan daya tahan siswa. sedangkan menurut penelitian yang dilakukan oleh erlinda Egi, dkk. (2017) dengan tidur dan istirahat yang cukup akan memberikan efek positif pada tubuh antara lain: kesehatan fisik, mental, emosi dan sistem imunitas tubuh.

\section{Kesegaran Jasmani Kategori Baik dan Baik Sekali}

Sebagian kecil siswa kelas IV dan V mengikuti pragram latihan setelah jam pembelajaran selesai, aktivitas diluar jam pembelajaran yang dilakukan salah satunya adalah olahraga basket, sepak bola dan futsal. Yang sangat seuai dengan teori komponen-komponen kesegaran jasmani Menurut Agus Mukholid (2004:4) salah satu untuk meningkatkan kesegaran jasmani adalah melalui latihan jasmani dan olahraga.

\section{Kesegaran Jasmani Kategori Kurang dan Kurang sekali}

Karena belum adanya program pembinaan untuk meningkatkan kesegaran jasmani siswa di luar jam pembelajaran yang bertujuan untuk menunjang dan meningkatkan kesegaran jasmani siswa khususnya di SD SIKK (Sekolah Indonesia Kota Kinabalu). Hal ini berkaitan dengan jenis latihan yang terbagi menjadi 2 jenis yaitu latihan untuk meningkatkan daya tahan aerobik dan latihan untuk meningkatkan daya tahan anaerobik

\section{KESIMPULAN}

Model Berdasarkan hasil penelitian dan pembahasan tentang profil tingkat kesegaran jasmani di SD SIKK Sabah Malaysia maka dapat disimpulkan profil tingkat kesegaran jasmani siswa SD SIKK dalam kategori cukup.

\section{DAFTAR PUSTAKA}

Abdullah, manaaji dan Agus M. 1994. Dasardasar Pendidikan Jasmani. Jakarta: Dedikbud.

Arikunto. 2010. Prosedur Pendekatan Penelitian Praktik. Jakarta : PT Rineka cipta

Depdikbud. 1977. Penilaian Kesegaran Jasmani Dengan Tes A.C.S.P.F.T. Jakarta

Egi, E, dkk. 2017. Hubungan Gangguan Tidur Dengan Tingkat Kesegaran Jasmani Remaja Puteri Di SMK Kertha Wisata Kelurahan Tlogomas Kecamatan Lowokwaru Malang. 2 (1) 293-303

https://publikasi.unitri.ac.id/index.php/fikes/ article/view/171 (07/07/2018)

Gilar M. 2017. Tingkat Kesegaran Siswa SD di Kabupaten Demak. Journal Of Physical Education, Sport, Health and Recreations, 6 (1), 38-44

https://journal.unnes.ac.id/sju/index.php/peshr/ article/view/13253(07/05/2018)

Harsuki. 2003. Perkembangan Olahraga Terkini Kajian Para Pakar. Jakarta :PT Raja Grafindo.

Mukholid. 2004. Pendidikan Jasmani. Yudhistira: Perpusnas

Hairy. 1989. Fisiologi Olahraga. Jakarta: Depdikbud

Santosa Giriwijoyo. 2013. Ilmu Kesehatan Olahraga. Bandung: PT Remaja Rosdakarya

Sugiyono. 2016. Metode Penelitian Pendidikan. Bandung: Alfabeta

Wirnantika, dkk. 2017. Survey Tingkat Kebugaran Jasmani Siswa Kelas IV SDN Pehrubuh dan MI Mambaul Hikam di Kabupaten Kediri Tahun Ajaran 2016/2017. 3 (2) 240-250 
Maulana Ischaq, dkk / Journal of Teaching Physical Education in Elementary School 2 (2) (2019)

http://ojs.unpkediri.ac.id/index.php/pjk/article/ view/11898 (19/10/2018) 